\title{
Os partidos políticos em formação no Brasil pós-2013 e a retórica anti-establishment político
}

\author{
Pâmela de Rezende Côrtes ${ }^{1}$ (1) \\ André Matos de Almeida Oliveira ${ }^{2}$
}

O objetivo deste artigo é saber se, entre julho de 2013, período imediatamente posterior às Jornadas de Junho, e junho de 2017, no Brasil, houve movimentos com retórica anti-establishment buscando tornarem-se partidos políticos. A avaliação foi empírico-descritiva, usando os programas dos movimentos. Para conceituar a retórica de um movimento como anti-establishment político, foram utilizados os três critérios de Abedi (2004). Concluímos que havia, no Brasil, no período estudado, partidos em formação que possuíam retórica anti-establishment político. $\mathrm{O}$ artigo pode contribuir tanto para o estudo da retórica anti-establishment político no Brasil quanto para o estudo dos partidos políticos em formação, um objeto que recebe pouca atenção acadêmica.

Palavras-chave: formação de partidos políticos; populismo; movimentos antiestablishment político; programa de partidos; Jornadas de Junho

\section{Introdução}

A crise da democracia tem sido alardeada por diversos teóricos e pode ser detectada com mais clareza estudando seus principais agentes institucionais, os partidos políticos. De acordo com Mair (2013), há uma renovação no interesse teórico pela democracia, mas o interesse coexiste com indicadores que apontam para uma indiferença popular à política feita de forma convencional. Para o autor, parte da explicação dessa indiferença está na crise de representação dos partidos políticos (Mair, 2013), que são importantes para ajudar a conformar e aprofundar a democracia entre os seus eleitores (Mattes et al., 2015, p. 229).

Dados da América Latina apontam que a consolidação da democracia na região ainda é frágil e que há muita desconfiança política entre os cidadãos (Power e Jamison, 2005). O informe do Latinobarómetro de 2018 apontou que "a democracia politizada na América Latina é um fenômeno novo" e em toda a região se percebe a perda de importância

\footnotetext{
1 Universidade Federal de Minas Gerais. Faculdade de Direito e Ciências do Estado. Belo Horizonte (MG), Brasil. Bolsista Capes. E-mail: <pamela.recortes@gmail.com>.

2 Universidade Federal de Minas Gerais. Faculdade de Direito e Ciências do Estado. Belo Horizonte (MG), Brasil. Bolsista Capes. E-mail: <andrematosalmeida@hotmail.com>.
} 
das instituições democráticas (Latinobarómetro, 2018, p. 21). Perigosamente, entre os brasileiros houve diminuição do apoio à democracia em 2018 em comparação a 2017, acompanhando a tendência da região. O Brasil é o último colocado na região em relação à satisfação com a democracia, e o número de pessoas que considera a democracia, mesmo tendo seus problemas, o melhor regime caiu 25 pontos percentuais desde 2013 , de $81 \%$ a 56\% em 2018 (Latinobarómetro, 2018, p. 30).

No Brasil, a crise de representação também pode se relacionar à existência de um número impressionante de partidos registrados e até mesmo que conseguem eleger cadeiras no parlamento nacional. No momento em que este artigo foi escrito, havia 35 partidos registrados no Tribunal Superior Eleitoral (TSE). O país apresenta, ainda, um dos mais altos índices de fragmentação partidária do mundo (Kinzo, 2004; Nicolau, 2017). Além da fragmentação, há no país uma falta de identificação dos eleitores com partidos: em 2015, 71\% de eleitores alegaram não possuir preferência partidária (Fraga, 2015), mas este não é um fenômeno exclusivo do contexto brasileiro (Dalton, McAllister e Wattenberg, 2003). Interessante ressaltar que, embora apresentando um alto índice de fragmentação, o sistema político-partidário brasileiro ainda mostra certa estabilidade (Alcántara e Freidenberg, 2002; Zucco Jr., 2015; Nicolau, 2017).

Os cidadãos parecem, portanto, demonstrar indiferença quanto às formas convencionais de fazer política. Os cidadãos latino-americanos que não mais declaram apoio à democracia parecem também apresentar indiferença com relação ao regime político. E esses indiferentes estão votando também de forma atípica, sem lealdade ideológica ou partidária (Latinobarómetro, 2018, p. 13).

Essa indiferença com as formas tradicionais de política e com as ideologias dos partidos foi acompanhada de movimentações de massa que bateram recordes de participação, com milhares de cidadãos indo às ruas. Uma das mais importantes, no Brasil, foram as chamadas Jornadas de Junho de 2013 (Moreira e Santiago, 2013, p. 13). Existe uma percepção compartilhada de que 2013 foi um ano fundamental na política nacional. Esses movimentos populares ocorridos em diversos estados brasileiros em 2013 não apresentavam coerência completa nem unicidade de bandeira. O que parecia ser-Ihes comum era o foco na "má qualidade dos serviços públicos, especialmente transportes, saúde, educação e segurança pública" (Gohn, 2014, p. 431). A recusa em eleger lideranças nas manifestações, para não gerar centralização ou hegemonia ideológica, também foi uma pauta central dos movimentos. O que unia as pessoas era a indignação contra as estruturas de poder vigentes (Gohn, 2014, p. 432).

As Jornadas de Junho tiveram pelo menos três momentos identificáveis: começando em São Paulo, um pequeno contingente reclamava contra o aumento das passagens do transporte público; a repressão policial e o uso desmedido de força inicia a segunda fase, que conseguiu agregar mais pessoas e mais frações da sociedade, ganha várias bandeiras e se espalha por vários estados do país; na última etapa, já arrefecendo, 
os movimentos se fragmentam e passam a ter pequenos núcleos com bandeiras mais definidas (Singer, 2013, p. 24-26).

A falta de liderança centralizada e a indignação generalizada reafirmam a crise dos partidos e de instâncias convencionais da política. A crise pode ser sintoma de alguma ruptura social mais profunda e do fim de uma era (Innerarity, 2017, p. 43). No mundo, o ano de 2011 foi um período de eclosão de diversas manifestações indignadas, que prefiguraram as mobilizações brasileiras. "Indignação" é uma palavra que "sintetiza um movimento que transformou o descontentamento generalizado com relação à política num novo tipo de protesto" (Innerarity, 2017, p. 157). Existem manifestações e movimentos que são "contra" alguma coisa e há dificuldade em traduzir esses movimentos como sendo a "favor" de algo. Essa conjuntura é ao mesmo tempo causa e efeito da indignação (Innerarity, 2017, p. 171).

Quando a indignação não é canalizada para algo mais concreto, torna-se terreno fértil para o crescimento de uma rejeição ao establishment político. O discurso antiestablishment tem crescido ao redor do mundo, ganhando importância entre partidos e candidatos. As pessoas que o endossam parecem ter objeções ao establishment, que se aprofundam numa combinação de reflexões pessoais e experiências negativas com as instituições vigentes e consolidam essa nova visão de mundo através da escolha de mídias alinhadas com ela (Kemmers, Van Der Waal e Aupers, 2016). Esses movimentos têm crescido em importância e conseguido sucesso eleitoral na Europa, apresentando um desafio importante à União Europeia e à própria globalização (March e Rommerskirchen, 2015; Hanley e Sikk, 2016; Hobolt, 2016).

A denominação desses discursos como anti-establishment político parece ser mais precisa do que outros termos que surgem para descrever o mesmo fenômeno, como "populismo", "antielitismo", "outsiders", "antissistema", "antipolítica" ou "antipartidismo" (Schedler, 1996; Barr, 2009). O populismo é o conceito mais ubíquo, mas é difícil definilo de forma precisa (Laclau, 2006, p. 15). Para Barr (2009, p. 38-39), o populismo reflete uma combinação específica de recursos, localização e vínculos, sendo um movimento de massa comandado por um outsider ou dissidente, que pode usar o apelo anti-establishment como forma de ganhar o poder ou manter-se nele, mas que, necessariamente, se vincula a demandas plebiscitárias. Dessa forma, populismo não é a retórica, mas o movimento ou projeto.

Outros autores, como Aslanidis (2016), por seu turno, afirmam que o populismo é um discurso colocado na esfera pública, enquanto Todorov (2012) o define como um discurso que tem como traço dominante, no plano formal, o que pode ser denominado "demagogia", "uma prática que, aqui, consiste em identificar as preocupações do maior número de pessoas e em propor, para aliviá-las, soluções fáceis de compreender, mas impossíveis de aplicar" (Todorov, 2012, p. 156). Para Mudde (2004), por fim, há duas interpretações comuns para o termo populismo. Na primeira, ele constitui um discurso simplista e de apelo altamente emocional, uma definição valiosa, mas difícil de 
operacionalizar em pesquisas empíricas. Na segunda interpretação, ele consiste em uma política oportunista que visa angariar apoio em vez de fazer boas escolhas. Para o autor, porém, a definição mais adequada é a de "populismo como uma ideologia que considera a sociedade separada, em última instância, entre dois grupos homogêneos e antagônicos entre si, 'o povo puro' versus 'a elite corrupta', e que argumenta que a política deve ser a expressão da vontade geral do povo".

Como afirma Abedi (2004), o termo "populismo" é difícil de operacionalizar na análise específica de partidos por duas razões: primeiro, porque as características do conceito não foram desenvolvidas, originalmente, para identificar propriamente partidos populistas, mas quaisquer movimentos, partidos ou indivíduos com essas tendências; segundo, as definições não são claras o suficiente com relação ao número de características (features) que o partido, movimento ou indivíduo precisam ter para serem qualificados como populistas (Abedi, 2004, p. 9).

Partindo de diversos outros estudos, Van Kessel (2011, p. 69-70) cria, posteriormente, uma classificação para partidos populistas, que serão assim considerados caso: "1) delineiem uma comunidade exclusiva de 'cidadãos comuns'; 2) apelem a esses 'cidadãos comuns' cujos interesses e opiniões devam ser centrais nas decisões políticas; e 3) sejam fundamentalmente hostis em relação ao establishment (político), que alegam não agir no interesse dos cidadãos comuns". Essa classificação é muito próxima a de Abedi (2004), apresentada adiante.

Outra expressão encontrada na literatura e que possui algumas convergências com o conceito escolhido é o de partido antissistema. O partido antissistema pode ser compreendido, de acordo com Zulianello (2018), como aquele que possui necessariamente duas propriedades: tem orientação ideológica que questiona as metapolíticas estabelecidas, para além de simples oposição; e não toma parte em relações de cooperação no nível sistêmico, tanto pela autopercepção de antagonista quanto pelas atitudes em relação aos demais partidos.

Uma terceira expressão que tem sido utilizada para avaliar partidos e que se assemelha à ideia de anti-establishment político é a de "partidos insurgentes". Analisando o sistema político do Reino Unido e comparando-o também com os da Áustria, EUA, Dinamarca, França e Itália, Flinders (2015, p. 244) afirma que os partidos insurgentes propuseram "uma divisão fundamental entre o establishment político e 'o povo' e posicionaram-se como uma 'marca desafiante', que promete entregar democracia sem política".

Ainda assim, ao avaliar o que de fato prometem, os partidos insurgentes parecem ser anti-establishment e não antipolítica, já que, no contexto britânico, eles também exigiam maior transparência e accountability dos representantes, oferecendo uma receita para uma política feita de forma diferente, em vez de uma não política. Assim, para os insurgentes, a democracia convencional é uma forma de perpetuar um grupo de elite no poder que falhou em sincronizar-se com as demandas e expectativas sociais (Flinders, 
2015, p. 245). Hartleb (2015, p. 42-43) afirma que a retórica anti-establishment critica o sistema partidário, afirmando que os partidos não cumprem mais suas funções e que as pessoas não se sentem mais motivadas a votar (considerando o sistema não obrigatório de voto). O voto nos partidos anti-establishment seria uma espécie de punição contra o mainstream político, mas talvez não seja necessariamente antipolítica.

Com base nessas considerações, o artigo empregará a denominação "antiestablishment político" para se referir ao seu objeto, mas é importante destacar que diversos trabalhos que serão citados ao longo do texto usam os demais termos apresentados acima. As citações não serão alteradas, porque não prejudicam a compreensão do texto. Os partidos anti-establishment político são aqueles que organizam o mundo político como um triângulo de atores e relações políticas, com um vértice ocupado pela classe política, outro pelo povo e outro por eles mesmos, o próprio partido. O primeiro vértice é o vilão; o segundo, a vítima inocente; e o terceiro, o herói redentor (Schedler, 1996). Buscando operacionalizar essa definição, Abedi (2004) aponta três critérios ${ }^{3}$ para a identificação desse tipo de partido. Ele deve ser:

- Um partido que desafia o status quo em termos de grandes questões políticas e questões do sistema político.

- Um partido que se percebe como um desafiante para as partes que compõem o establishment político.

- Um partido que afirma que existe uma divisão fundamental entre o establishment político e as pessoas. Isso implica que todos os partidos do establishment, sejam eles de governo ou de oposição, são essencialmente os mesmos (Abedi, 2004, p. 12, tradução livre dos autores).

Para o autor, o partido deve cumprir necessariamente os três requisitos para ser considerado um partido contrário ao establishment político. Esses critérios já foram utilizados com objetivos classificatórios por Abedi, 2004; Abedi e Lundberg, 2009; Van Spanje, 2011.

O objetivo deste artigo, porém, é avaliar, por meio de um levantamento de propostas de partidos políticos pós-2013, se estão surgindo partidos, no Brasil, com retórica anti-establishment político. Importante ressaltar que, acompanhando Polk et al. (2017, p. 3), não encontramos nenhuma medida específica de saliência de retórica antiestablishment nos níveis partidários. Dessa forma, usaremos os critérios de Abedi (2004) como uma forma de análise da retórica anti-establishment político. Essa análise da retórica é preliminar, já que não encontramos outros trabalhos que analisem a retórica ou que usem os aspirantes a partidos políticos como objetos. Assim, este artigo não tem o objetivo de classificar os movimentos ideologicamente, nem de investigar a ação ou o

\footnotetext{
3 Os critérios estabelecidos por Abedi (2004) foram desenvolvidos com vistas a classificar partidos institucionalizados e sua atuação política. Decidimos por adaptá-los, aplicando-os às propostas dos partidos em formação.
} 
comportamento desses movimentos (seria inadequado, como apontam Krouwel e Van Elfrinkhof, 2014).

Para observar o contexto brasileiro, foram utilizadas, como parâmetro, as Jornadas de Junho de 2013. Decidimos não nos ater aos partidos registrados, mas aos movimentos que almejam se tornar partidos políticos. Consideramos que o momento logo posterior às Jornadas de Junho seria oportuno para o surgimento desses partidos, mas que seria difícil saber quando - e se - esses movimentos aspirantes a partidos políticos conseguiriam cumprir todos os requisitos legais para se consolidarem. Também é importante ressaltar que esse recorte pode estar subestimando a oferta de movimentos com retórica antiestablishment político, já que muitos movimentos podem não cumprir os requisitos para se tornar aspirantes a partidos.

Eis como o texto se desenvolve. Na próxima seção, "Seleção dos programas dos partidos", explicamos as etapas que os programas devem percorrer para conseguir registro pelo TSE e listamos os partidos que foram selecionados para a análise. Na seção seguinte, "Aplicação dos três critérios de Abedi", esclarecemos o conteúdo dos critérios e como eles se relacionam entre si, bem como a forma como eles foram aplicados para classificar os programas dos partidos políticos. Por fim, na seção "Análise dos programas antiestablishment", apresentamos os três programas, entre todos os selecionados, que satisfizeram aos critérios de Abedi e que podem, portanto, ser classificados como propostas de partidos anti-establishment político. Discorremos com mais detalhes sobre os conteúdos desses programas, para explicitar suas propostas e para mostrar por que elas satisfazem aos critérios de Abedi. Encerramos o texto, nas "Considerações finais", com a conclusão de que podem, sim, ser detectadas propostas de partidos anti-establishment político no Brasil no período em análise. Fazemos algumas considerações sobre possíveis limitações nos métodos de Abedi e indicamos outros partidos, além dos três previamente selecionados, que talvez também possam ser classificados como anti-establishment político.

\section{Seleção dos programas dos partidos}

Tendo as Jornadas de Junho como marco, procuramos descobrir quais partidos estão tentando registro no TSE e, por meio da avaliação de seus programas ou manifestos, verificar se eles se encaixam na retórica anti-establishment político. Como apontado, não foram encontrados trabalhos que avaliem a retórica anti-establishment político. Tampouco pudemos encontrar, infelizmente, pesquisas que avaliem os movimentos que estão tentando registro como partidos políticos no país.

Como consta no artigo 90 da Resolução do TSE no 23.571/18, para que um movimento postulante a partido consiga registro no Tribunal Superior Eleitoral, é preciso que possua no mínimo 101 fundadores provenientes de, pelo menos, um terço dos estados do país. Esses fundadores devem redigir o estatuto e o programa do partido político, que 
devem ser publicados no Diário Oficial da União antes mesmo do registro no Tribunal Superior Eleitoral (artigo 90, caput e parágrafo 10, da Resolução 23.571/18 do TSE).

Dessa forma, o movimento que visa efetuar o registro precisa ter um manifesto ou programa com os princípios que serão norteadores a partir de sua fundação. O manifesto ou programa do partido é o documento em que os partidos expressam seus valores e objetivos e que tem, inclusive, poder vinculativo sobre os políticos pertencentes à sigla; um político poderá ser excluído se ferir, repetidamente, os valores do partido, como dispõe o inciso I do artigo 22-A da Lei no 9.096/95.

Esse é apenas um dos muitos passos necessários para o registro de um partido político no país. No site do TSE, constam 77 partidos em formação, aguardando alcançar o apoiamento mínimo de cidadãos para conseguir efetivar o registro do estatuto perante o TSE até dezembro de 2019. Como disposto no parágrafo primeiro do artigo 70 da Lei no 9.096/95,

$\S 1^{0}$ Só é admitido o registro do estatuto de partido político que tenha caráter nacional, considerando-se como tal aquele que comprove, no período de dois anos, o apoiamento de eleitores não filiados a partido político, correspondente a, pelo menos, $0,5 \%$ (cinco décimos por cento) dos votos dados na última eleição geral para a Câmara dos Deputados, não computados os votos em branco e os nulos, distribuídos por um terço, ou mais, dos Estados, com um mínimo de $0,1 \%$ (um décimo por cento) do eleitorado que haja votado em cada um deles.

Partindo dessas informações, pesquisamos quais movimentos buscaram registro de partido político, tendo como chave de pesquisa no Diário Oficial da União ${ }^{4}$ os termos "manifesto do partido" e "programa de partido". Os dados foram coletados no segundo semestre de 2017, e o período abrangido pela pesquisa vai de julho de 2013 até junho de 2017. Esse recorte temporal se justifica porque estamos considerando a influência das Jornadas de Junho no registro de partidos. É interessante considerar, porém, que outros movimentos podem ter levado à criação de partidos com retórica anti-establishment político, e uma nova onda de análise ampliando o marco temporal poderia compreender se as Jornadas de Junho foram causa para o resultado ou se há outros elementos a serem considerados. Os movimentos que possuíam manifesto ou programa registrado de julho de 2013 a junho de 2017 estão discriminados no Quadro 1 e totalizam 51 movimentos:

\footnotetext{
${ }^{4}$ Fizemos a pesquisa no Diário Oficial da União em 2017, no sistema antigo de busca.
} 


\section{Quadro 1}

Manifestos e programas de movimentos candidatos a partidos que buscaram registro (julho de 2013 a junho de 2017)

\begin{tabular}{|c|c|}
\hline $\begin{array}{c}2013 \\
\text { (De julho a dezembro) }\end{array}$ & $\begin{array}{l}\text { Partido da Força Popular - PFP; } \\
\text { Partido da Saúde e Educação - PSE; } \\
\text { Partido do Brasil Forte - PBF; } \\
\text { Partido do Servidor Público e Privado - PSPP; } \\
\text { Partido Nacional Indígena - PNI; } \\
\text { Partido Pirata do Brasil - PIRATAS; } \\
\text { Partido Renovador Cristão - PRC; } \\
\text { Total: } 7\end{array}$ \\
\hline 2014 & $\begin{array}{l}\text { Partido Ativistas da Paz pela Vida - PAZ; } \\
\text { Partido Consciência Democrática - PCD; } \\
\text { Partido da Integração Social e Cidadania - PISC; } \\
\text { Partido da Nova Ordem Social - NOS; } \\
\text { Partido do Combate ao Desemprego - PCD; } \\
\text { Partido do Mérito Municipalista - PMM; } \\
\text { Partido Igualdade - IDE; } \\
\text { Partido da Solidariedade Nacional - PSN; } \\
\text { Partido Muda Brasil - MB; } \\
\text { Partido Nacional Corinthiano - PNC; } \\
\text { Partido Participação - PAR; } \\
\text { Partido pela Acessibilidade e Inclusão Social - PAIS; } \\
\text { Partido Republicano Cristão Brasileiro - PRCB; } \\
\text { Partido Social da Família Brasileira - PSFB; } \\
\text { Partido Social Trabalhista - PST; } \\
\text { Partido União da Democracia Cristã do Brasil - UDCdoB; } \\
\text { Partido Desbravador - PD; } \\
\text { Total: 17 }\end{array}$ \\
\hline 2015 & $\begin{array}{l}\text { Partido da Juventude - PJ } \\
\text { Partido da Real Democracia Parlamentar - RDP; } \\
\text { Partido da Reedificação da Ordem Nacional - PRONA; } \\
\text { Partido da Renovação da República - PRR; } \\
\text { Partido das Organizações Democráticas - POD; } \\
\text { Partido Democrata Cristão - PDC; } \\
\text { Partido do Esporte - PE; } \\
\text { Partido Força Brasil - FB; } \\
\text { Partido Nacional da Saúde - PNS; } \\
\text { Partido Patriotas - PATRI; } \\
\text { Partido Político RENOVAR - RNV; } \\
\text { TOTAL: } 11\end{array}$ \\
\hline 2016 & $\begin{array}{l}\text { Partido ANIMAIS; } \\
\text { Partido Conservador - PACO; } \\
\text { Partido da Evolução Democrática - PED; } \\
\text { Partido da Frente Favela Brasil - FRENTE; } \\
\text { Partido da União Democrática Nacional - UDN; } \\
\text { Partido do Pequeno e Micro Empresário Brasileiro - INOVA BRASIL; } \\
\text { Partido Humanitário Nacional - PHN; } \\
\text { Partido Liga Democrática Liberal - LIGA; } \\
\text { Partido Raiz - Movimento Cidadanista; } \\
\text { Partido Reformista Democrático - PRD; } \\
\text { Partido Unidade Popular - UP5; } \\
\text { Total: } 11\end{array}$ \\
\hline
\end{tabular}

5 O Partido Unidade Popular conseguiu seu registro no final de 2019, mas vale lembrar que os dados foram coletados em 2017 e, nessa época, o partido ainda buscava registro. 


\begin{tabular}{|c|l|}
\hline \multirow{2}{*}{2017} & $\begin{array}{l}\text { Partido da Reestruturação da Ordem Nacional - PRONA; } \\
\text { Partido da Regeneração e da Moral - PRM; } \\
\text { Partido Igualdade Brasil - IB; }\end{array}$ \\
$\begin{array}{l}\text { Partido Social da Família - PSF; } \\
\text { Partido Tribuna Popular; } \\
\text { Total: } 5\end{array}$
\end{tabular}

Fonte: Elaborado pelos autores com base nos dados extraídos do Diário Oficial da União em 2017.

Usando os três critérios de Abedi (2004), buscamos avaliar quais programas ou manifestos indicavam que os movimentos tinham uma retórica anti-establishment político. Faremos uma análise mais aprofundada dos partidos que satisfizerem aos três critérios propostos.

Deve ficar claro que estamos avaliando a retórica anti-establishment político dos partidos, e não a sua real atuação como partido anti-establishment político. Investiga-se o discurso dos partidos, e não necessariamente sua ação. Essa é uma distinção importante, que, não obstante, pode se acomodar aos critérios de Abedi, já que não é possível que algum partido satisfaça a qualquer dos três critérios sem ter uma retórica antiestablishment político.

Desnecessário dizer, também, que o programa de um partido político não é o único local em que se pode apresentar a retórica anti-establishment político. No entanto, o documento é importante, especialmente para um partido que busca registro, já que é a exposição pública e institucionalizada dos valores que o nortearão.

Por fim, como última ressalva, é preciso esclarecer que nossa análise não é valorativa. Um partido que adota retórica anti-establishment político não é considerado, neste artigo, mais ou menos legítimo do que um partido que adota uma retórica próestablishment político. Não se deve confundir uma retórica anti-establishment político com uma retórica radical ou extremista. Um juízo de valor sobre o discurso contra as elites está em compasso com um juízo de valor sobre as elites. Logo, presumir que toda retórica crítica às elites é radical é também presumir que apenas retóricas favoráveis às elites podem ser moderadas, o que parece falso. Existem muitas elites no mundo. É bastante provável que algumas delas só possam ser apoiadas por discursos radicais e que, portanto, adotar um discurso mais moderado é se confrontar com elas. Assim, acreditamos não haver nenhuma correspondência fixa entre um tipo de retórica (anti ou pró-establishment político) e a legitimidade política dessa retórica.

O mesmo vale para a ideologia. Neste artigo, partiremos do pressuposto de que não há uma correspondência fixa entre a ideologia e a retórica anti-establishment político. Mais à frente, veremos que essa retórica pode ser adotada tanto para defender posturas comumente vistas como alinhadas à direita do espectro ideológico (ex.: posições nacionalistas e posições anti-imigração) como para defender posturas vistas em geral como alinhadas à esquerda do espectro ideológico (ex.: críticas a grandes corporações e posições ambientalistas). Para ilustrar, ao falar sobre partidos populistas, Schumacher e Van Kersbergen (2016, p. 302) apontam que eles se colocarão contrários à elite percebida no poder e que o discurso contra essas elites pode variar a depender da situação política 
concreta. Se a elite for considerada neoliberal, por exemplo, o discurso populista tende a se colocar contrário ao neoliberalismo. Mas, se as elites forem percebidas como favoráveis ao Estado de bem-estar social, o populismo se colocará contrário a este. Então, correspondências ideológicas entre os partidos populistas são difíceis de detectar.

\section{Aplicação dos três critérios de Abedi}

Na Quadro 2 apresentamos os três critérios de Abedi (2004) para detectar uma retórica anti-establishment político de um partido:

\section{Quadro 2 \\ Lista dos critérios para a retórica anti-establishment político de um partido, segundo Abedi}

\begin{tabular}{|c|l|}
\hline \multicolumn{2}{|c|}{ Critérios de Abedi } \\
\hline $\begin{array}{c}10 \\
\text { critério }\end{array}$ & $\begin{array}{l}\text { Um partido que desafia o status quo em termos de grandes questões políticas e } \\
\text { questões do sistema político. }\end{array}$ \\
\hline $\begin{array}{c}20 \\
\text { critério }\end{array}$ & $\begin{array}{l}\text { Um partido que se percebe como um desafiante para as partes que compõem o } \\
\text { establishment político. }\end{array}$ \\
\hline $\begin{array}{c}30 \\
\text { critério }\end{array}$ & $\begin{array}{l}\text { Um partido que afirma que existe uma divisão fundamental entre o establishment } \\
\text { político e as pessoas. Isso implica que todos os partidos do establishment, sejam eles } \\
\text { de governo ou de oposição, são essencialmente os mesmos. }\end{array}$ \\
\hline
\end{tabular}

Fonte: Elaborado pelos autores com base em Abedi (2004).

Como os critérios são gerais, buscamos averiguar que temas políticos poderiam encaixar-se neles. Consideramos esse detalhamento necessário para esclarecer quais tipos de afirmações concretas devem ser buscadas nos manifestos.

Abedi (2004), ao aplicar seus critérios a três partidos europeus, elegeu alguns exemplos de temas que são relevantes para cada critério:

10 critério: Um partido que desafia o status quo em termos de grandes questões políticas e questões do sistema político. Os partidos anti-establishment político advogam grandes mudanças no sistema político do país, desafiando o status quo. Para Abedi (2004, p. 14), as mudanças poderiam ser apresentadas, por exemplo, como grandes propostas de descentralização de poder, baseadas na alegação de que a centralização viola os interesses regionais. A descentralização demandaria profundas mudanças institucionais e políticas, e até implicaria a separação de algumas regiões; para ele, o partido Lega Nord, na Itália, apresenta uma proposta desse tipo. Outra pauta que, para Abedi (2004, p. 15), se conforma ao critério é a proposição de profundas mudanças no sistema de representação, substituindo, por exemplo, sistemas de representação partidária proporcional por formas mais diretas de atuação dos cidadãos. De fato, tais propostas sempre têm a ver com a diminuição do papel dos partidos no processo político e o aumento da participação do cidadão individual. Um exemplo de pauta desse tipo é o do FPO, um 
partido de extrema direita austríaco que busca fundar uma "nova república", menos dominada pelos partidos. Outro exemplo é a proposta de uma "democracia de base" (grassroots democracy) para garantir a participação do cidadão e retirar poderes do establishment político. Para Abedi, o Partido Verde alemão sustentava essa proposta, ao menos até certo período.

20 critério: Um partido que se percebe como um desafiante para as partes que compõem o establishment político. Os partidos anti-establishment político fazem fortes e constantes críticas a todo o establishment político. Essa retórica passa a ser vista como fundamental à identidade do partido. Para Abedi (2004, p. 16-17), normalmente as críticas têm o mesmo conteúdo: afirma-se que os partidos do governo são corruptos, clientelistas, cartelizados, patrocinados por interesses privados, ineficientes e incapazes de resolver reais problemas etc. A Lega Nord, o FPO e os Verdes alemães fizeram críticas desse tipo ao establishment político, segundo Abedi.

$3^{\circ}$ critério: Um partido que afirma que existe uma divisão fundamental entre $o$ establishment político e as pessoas. Isso implica que todos os partidos do establishment, sejam eles de governo ou de oposição, são essencialmente os mesmos. Os partidos antiestablishment político enfatizam as diferenças entre eles e o mainstream. Segundo Abedi (2004, p. 18), eles afirmam que há uma profunda divisão entre os cidadãos comuns e os partidos que compõem o governo, e se põem firmemente do lado dos cidadãos. Assim, eles se distanciam dos outros partidos e se veem como outsiders. Afirmam que os partidos do establishment político buscam apenas proteger seus próprios interesses e bloqueiam mudanças políticas que colocariam em risco sua hegemonia. Os partidos antiestablishment político, representando o cidadão comum, buscariam precisamente encerrar essa hegemonia. Mais uma vez, Abedi considera que tanto Lega Nord quanto FPO e Verdes alemães satisfazem a esse critério.

Esses são temas que Abedi considera que satisfazem aos seus três critérios. Ele mesmo afirma, porém, que essa lista não é exaustiva. De qualquer forma, os exemplos temáticos esclarecem o caminho da análise: 


\section{Quadro 3}

\section{Exemplos de temas que satisfazem aos critérios de Abedi}

\begin{tabular}{|c|c|}
\hline Critérios de Abedi & $\begin{array}{c}\text { Partido satisfaz ao critério quando } \\
\text { (rol exemplificativo) }\end{array}$ \\
\hline $\begin{array}{l}10 \text { critério. Um partido que desafia o } \\
\text { status quo em termos de grandes } \\
\text { questões políticas e questões do } \\
\text { sistema político. }\end{array}$ & $\begin{array}{l}\text { - Propõe mudanças institucionais profundas, como a ampla } \\
\text { descentralização política, novos sistemas de representação } \\
\text { partidária, mecanismos de democracia direta, etc.; } \\
\text { - Propõe a diminuição da participação dos partidos e o aumento } \\
\text { da participação direta do cidadão; } \\
\text { - Propõe noções de democracia de base (grassroots democracy). }\end{array}$ \\
\hline $\begin{array}{l}20 \text { critério. Um partido que se percebe } \\
\text { como um desafiante para as partes } \\
\text { que compõem o establishment } \\
\text { político. }\end{array}$ & $\begin{array}{l}\text { - Faz fortes e constantes críticas a todo o establishment político; } \\
\text { - Acusa as elites de corruptas, clientelistas, cartelizadas, } \\
\text { patrocinadas por interesses privados, ineficientes e incapazes de } \\
\text { resolver reais problemas etc. }\end{array}$ \\
\hline $\begin{array}{l}30 \text { critério. Um partido que afirma que } \\
\text { existe uma divisão fundamental entre } \\
\text { o establishment político e as pessoas. } \\
\text { Isso implica que todos os partidos do } \\
\text { establishment, sejam eles de governo } \\
\text { ou de oposição, são essencialmente } \\
\text { os mesmos. }\end{array}$ & $\begin{array}{l}\text { - Afirma que há uma divisão profunda entre o establishment } \\
\text { político e os cidadãos, e se coloca do lado dos cidadãos; } \\
\text { - Afirma que os partidos tradicionais buscam apenas proteger } \\
\text { seus interesses, bloqueando mudanças que colocariam em risco } \\
\text { sua hegemonia; } \\
\text { - Adota a retórica do outsider, que se distancia dos partidos } \\
\text { governistas e pretende encerrar sua hegemonia. }\end{array}$ \\
\hline
\end{tabular}

Fonte: Elaborado pelos autores com base em Abedi (2004).

Para o autor, um partido tem retórica anti-establishment político apenas quando cumpre todos os três critérios. Dessa forma, não há possibilidade de uma visão gradualista dessa retórica (diferente do adotado com relação ao populismo por Balcere, 2014). Seguiremos o entendimento de Abedi (2004) neste artigo. Portanto, o programa do partido deverá satisfazer a todos os três critérios para justificar a conclusão de que tem retórica anti-establishment político.

A aplicação dos três critérios aos programas dos partidos políticos ocorreu por etapas eliminatórias. Cada critério foi aplicado separadamente, e apenas os programas que satisfaziam a um dos critérios eram analisados pelo critério subsequente. Então, os programas de partido que não satisfizeram a um dos três critérios foram eliminados da análise posterior. Além disso, por ser mais conveniente, decidimos aplicá-los em ordem invertida: começamos pelo terceiro critério, depois passamos ao segundo critério e, por último, ao primeiro critério.

Esse procedimento pareceu mais conveniente por duas razões. Primeiro, porque, em nossa opinião, o terceiro critério motiva uma retórica um pouco mais direta e facilmente detectável do que a dos outros dois e, por isso, facilita o início da análise. Segundo, e mais importante, porque o primeiro critério, se não aplicado com especial atenção, pode gerar problemas no cenário de nossa análise. É de presumir que todos os movimentos que aspiram a se tornar partidos políticos têm pretensões de mudar "o status quo" e as "grandes questões políticas e questões do sistema político" (do contrário, por que pretenderiam se tornar partidos políticos?). Há, assim, o risco de aplicar o primeiro critério a situações demais, gerando muitos "falsos positivos". Presume-se que os "falsos positivos" 
seriam corrigidos ao aplicar o segundo e o terceiro critérios, que são bem mais restritivos que o primeiro. Mesmo assim, os riscos de erro e vieses de análise aumentariam. Assim, para diminuir esses riscos, a decisão de inverter a ordem de aplicação dos critérios parece mais razoável, já que a ordem em que os critérios são aplicados é irrelevante para o resultado da análise dos textos. Com o primeiro critério sendo aplicado somente depois da aplicação do terceiro e do segundo critérios, já haverá elementos indicando que a retórica de um partido pode ser anti-establishment político e, portanto, os riscos de erros e vieses diminuirão.

Outro ponto que vale destacar é que a aplicação dos critérios ocorreu por passos, mas os textos dos programas dos partidos não necessariamente seguem essa ordem analítica. Não é incomum, por exemplo, que uma mesma passagem de um texto expresse uma ideia que ao mesmo tempo satisfaça a dois ou até aos três critérios de Abedi. Em situações assim, cada critério será aplicado separadamente, mas sempre seremos conduzidos à mesma passagem do texto.

Dos 51 programas analisados, apenas três se adequaram aos três critérios de Abedi, apresentando retórica anti-establishment político. Os três programas são: o do Partido Nacional Indígena, o do Raiz - Movimento Cidadanista e o do Partido Tribuna Popular. A seguir, explicaremos o caminho de análise de cada um desses programas.

\section{Análise dos programas anti-establishment}

\section{Partido Nacional Indígena (PNI)}

O primeiro movimento a ser analisado é o PNI, Partido Nacional Indígena. Ele possui um programa longo, publicado em 4 de julho de 2013, que ocupa três páginas do Diário Oficial da União. Ele desafia o establishment político de forma direta e pode ter bons motivos para fazê-lo, já que representa uma minoria que realmente costuma estar à margem do sistema político brasileiro. Não apresenta uma linguagem agressiva e possui um programa equilibrado e coerente.

No início do texto, o programa narra como o movimento tentou colaborar com outros que também tinham pautas minoritárias para ocupar espaços políticos em 2004 e como, com o desenrolar das discussões, foi preterido e concluiu que seria preciso criar um partido próprio. Afirma que, desde a transição para o regime democrático e a Constituição de 1988, os povos indígenas "conseguiram ter suas participações nos poderes públicos, mas geralmente abonando propostas que interessavam na maioria das vezes ao Estado, sendo voto vencido nas decisões, principalmente nos conselhos deliberativos" (Partido Nacional Indígena, 2013, p. 191).

Partindo para a análise do terceiro critério, qual seja, de afirmar que existe uma diferença fundamental entre o establishment e as pessoas, o programa o cumpre ao criticar as elites e os partidos de forma direta. Como se demonstrou, embora esse critério possa 
ser preenchido de algumas formas, é comum que o faça, como apontado por Abedi (2004), através da homogeneização dos atores políticos mainstream, apontando-os como incapazes de cumprir aquilo que prometem ou os objetivos para os quais foram criados (Quadro 3). No texto do programa, numa primeira passagem, afirma-se que "as elites brasileiras não foram capazes de construir uma grande civilização democrática para todo o povo brasileiro incluindo os indígenas no contexto nacional" (Partido Nacional Indígena, 2013, p. 191). Isso implica dizer que a elite não apenas é uniformemente incapaz, mas também não é capaz de responder aos anseios dos marginalizados, que aqui estão representados pelos índios, porém em diversas outras partes do texto estão agrupados como todos os excluídos. No trecho intitulado "Princípios básicos do PNI", vemos essa atribuição de representantes do agrupamento maior, ao afirmar que:

II. O PNI nasce pretendendo ser a expressão política da maioria da população brasileira, oprimida e explorada por um regime econômico voltado para a satisfação de uma pequena minoria. Identifica-se, primordialmente, com as lutas e os interesses dos índios e da grande massa de marginalizados e excluídos (Partido Nacional Indígena, 2013, p. 191).

Ainda dentro da análise do terceiro critério, o texto homogeneíza não só as elites dominantes, mas também os partidos políticos. O programa indica que os índios "sempre viveram sob regimes opressores, sempre excluídos de tudo e de todos" (Partido Nacional Indígena, 2013, p. 191) e que aí está a importância de se organizarem em partido, já que "não se pode aceitar mais ser puxados pela mão, tomando decisões contrárias as (sic) reivindicações dos índios e das classes mais excluídas do Brasil" (p.191). Caso não o façam, continua o texto, e se mantenham "Sem organização partidária, quem decide são os governos e as cúpulas partidárias contrárias aos interesses dos povos indígenas no Brasil, principalmente nas questões fundiárias" (p. 191). Ou seja, as cúpulas partidárias, todas iguais, não estão olhando para os marginalizados, que serão, portanto, contemplados pelo referido movimento.

O programa cumpre o segundo critério, ou seja, de se perceber como um desafiante do establishment, quando afirma que o "PNI nasce sendo o único meio de incluir os índios através da eleição no Congresso Nacional, mas também no plano estadual e municipal" (Partido Nacional Indígena, 2013, p. 191). Ou seja, não só há uma distinção fundamental entre o establishment e as pessoas, como também há a alegação de que o movimento será capaz de desafiar o establishment e é a única forma de inclusão dos marginalizados por ele representados. O programa aponta ainda que o movimento é "indispensável para a democracia e a inclusão dos excluídos, usando o pluralismo étnico existente no Brasil, sendo o sistema mais adequado para a expressão da heterogênea sociedade brasileira" (p. 191). O programa ainda traz a representação do establishment como essencialmente desonesto, o que, como vimos, é uma das formas de expressão do segundo critério (Quadro 3). Os partidos do establishment pretensamente incluiriam os índios, mas isso nunca se concretizou de fato: o "PNI tem como princípio a realidade social 
do país, a verdade e a honestidade no jogo político, pois se chegou à conclusão (sic) que nada adianta prometer o paraíso aos índios e não índios membros do PNI, se não se tem os meios para realizar e nem garantir nada" (p. 191).

Ainda noutro ponto, o movimento é incisivo ao dizer que se apresenta como um desafio ao mainstream e ao criticar as elites que subjuga os seus representados. $O$ programa diz que o movimento é capaz de identificar "o poder político existente a superar. O desafio está em como inserir os índios no contexto político se ainda se encontram alienados, enfrentando o preconceito e o racismo, vivendo inclusive uma crise de identidade em algumas regiões do País, fomentada pela opressão da elite constituída que está no comando de seus destinos" (Partido Nacional Indígena, 2013, p. 191). Ainda, nos chamados princípios básicos, o programa aponta a importância de reconhecer o povo indígena como "sujeito, o fundamento e o fim de todas as instituições e das medidas econômicas, sociais e políticas" (p. 191), reclamando que ele "Não pode ser considerado mero objeto, coisa ou instrumento da economia, do Estado, do partido ou do processo histórico" (p. 191). Ou seja, há uma elite no comando que oprime e reifica o povo indígena, e o movimento pretende superá-la através de sua institucionalização em formato de partido político.

A análise do primeiro critério, como foi explicado, só faz sentido quando satisfeitos os dois outros critérios propostos por Abedi. O que importa é que o partido não só faça as críticas ao establishment, mas também que acredite que, para superá-las, será preciso fazer grandes ações, grandes reformas e grandes mudanças. O programa do movimento faz uma crítica ao país desde a sua fundação, afirmando que desde o início imperaram "a ineficácia governamental, de exclusão e injustiça sociais insuportáveis" (Partido Nacional Indígena, 2013, p. 191), sendo os indígenas "o povo (...) mais afetado". E então faz um apelo a uma democracia mais direta, que é um dos recursos mais comuns dentre os partidos anti-establishment, como demonstrado por Abedi (2004) e reforçado por Hartleb (2015, p. 44). No ponto intitulado "Participação Política, Recrutamento e Legitimação dos Índios e Não Índios", o programa afirma a importância da "manutenção das formas de democracia direta da população", que introduzem "um importante elemento de controle popular na gestão dos negócios públicos nas três esferas de governo" (p. 192) e estão previstos na Constituição.

Outra proposta, no ponto intitulado "Integração e Descentralização do Desenvolvimento", é a de "Descentralizar o País a partir de uma política de municipalização" (Partido Nacional Indígena, 2013, p. 192). Aqui, retornam as propostas de descentralização do poder, comuns na retórica anti-establishment político, como apontado por Abedi (2004) e apresentado acima (Quadro 3). O apelo é a uma "grande mudança estrutural na sociedade brasileira, incluindo como prioridade os índios e os mais excluídos da sociedade (p. 192)". Por fim, no ponto denominado "Novo Desenvolvimento Social aos Povos Indígenas no Brasil", o programa indica que talvez ainda não exista democracia real para os povos indígenas, já que: 
a democracia proporcionará efetiva melhoria no dia a dia dos índios e não índios, através de um tipo de desenvolvimento muito diferente do atual, que é sustentado pelo uso predatório dos recursos, pela exploração de mão de obra abundante e barata, pela socialização dos ônus de construção e manutenção de infraestruturas, pelas manobras fiscais e, sobretudo, pela concentração de renda levada a limites extremos (Partido Nacional Indígena, 2013, p. 193).

É interessante destacar que esse movimento talvez não tenha tido nenhuma influência das Jornadas de Junho, mas faça parte de uma outra movimentação política brasileira calcada em movimentos sociais tradicionais e pode ter sido impulsionado (mas não criado, uma vez que o movimento relata debater a proposta desde 2004) pela comoção nacional gerada pela "carta da comunidade Guarani-Kaiowá para a Justiça e o Governo Brasileiro" (Freitas, 2012). Essa carta afirmava "que os índios estariam dispostos a se suicidar coletivamente em protesto contra a decisão judicial", de setembro de 2012, que ordenava a "retirada dos índios Guarani-Kaiowá do acampamento Pyelito Kue/Mbarakay, na Fazenda Cambará, em Iguatemi, Mato Grosso do Sul (MS)" (s.p.).

\section{Raiz - Movimento Cidadanista}

O próximo aspirante a partido é o Raiz - Movimento Cidadanista. Ele possui um programa relativamente extenso, publicado em 6 de maio de 2016. As "raízes do projeto político" que apresenta estão em três ideias: Teko Porã, "conceito político, econômico e social que tem por referência a visão dos povos originários da América", uma "filosofia que está na nossa alma original e significa viver em aprendizado e convivência com a natureza"; Ubuntu, uma ética que "representa o rompimento com o individualismo"; e Ecossocialismo, que ocorre "quando o socialismo se encontra com a ecologia" (Raiz Movimento Cidadanista, 2016, p. 219).

Outro eixo fundamental do texto é o Cidadanismo, que tem como "objetivo histórico" a "universalização dos direitos da cidadania", e "está intimamente ligado à noção de soberania popular, estampada no parágrafo do primeiro artigo da Constituição Federal brasileira: 'todo poder emana do povo, que o exerce por meio de representantes eleitos ou diretamente'"' (Raiz - Movimento Cidadanista, 2016, p. 219).

Partindo para a análise do terceiro critério, percebe-se que este é preenchido quando se delineia quem compõe o movimento. Os integrantes do movimento, primeiro, se apresentam como "brasileiras e brasileiros de todas as cores e identidades, gêneros e transgêneros, diversidade, mistura, inclusão, visíveis e invisíveis, e não paramos de chegar". E o texto continua, afirmando serem estes "quem sustenta as minorias que se sustentam das maiorias, mas nossa vontade não é respeitada" (Raiz - Movimento Cidadanista, 2016, p. 219). Ou seja, percebe-se aqui que o movimento se considera representante da maioria que não se vê respeitada. Na sequência, o programa faz a crítica 
direta ao establishment político, afirmando que "Várias vezes já vimos mudar os rostos, os gestos, partidos ou siglas, mas sempre para servir aos que já mandam" (219). Os que mandam são "a casta econômica e a casta política", que se relacionam de forma "promíscua" e fazem a "nossa democracia" ser "sequestrada pelo dinheiro, corrompida pelo poder e distorcida pela ignorância" (p. 219). Ou seja, o movimento afirma que não importam as mudanças políticas que ocorrem, já que são todos os políticos iguais, são todos componentes dessa "casta".

O movimento não só aponta a ocupação das instituições por uma "casta" indistinta, como, na sequência, cumpre o segundo critério, colocando-se como diferente do establishment político, como um desafiante. Ele desafia ao afirmar, primeiro, que não busca "o poder pelo poder", nem pretende se "alienar na disputa por aparatos, em que o poder deixa de ser um meio de transformação da realidade para tornar-se um fim em si mesmo" (p. 219). Segue ainda apontando suas diferenças em relação ao establishment, ao dizer que, "Para corresponder às expectativas da sociedade", não pretende "repetir os modelos organizativos do passado", mas propõe:

horizontalidade e interatividade nas instâncias deliberativas, garantindo o efetivo empoderamento social para uma nova forma de fazer política. Daí a necessidade de um novo ator político que se construa a partir das propostas e reivindicações que surgem das mobilizações sociais, ambientais, culturais e políticas, com a participação livre e aberta a qualquer cidadão. É preciso radicalizar a democracia, para que os cidadãos mandem e o governo obedeça (Raiz - Movimento Cidadanista, 2016, p. 219).

Uma nova menção a esse establishment inadequado do qual o movimento pretende se distanciar se encontra na sequência da explicação do "Cidadanismo", quando o programa aponta que o poder constitucionalmente reconhecido do povo "vem sendo sequestrado por oligarquias que se apoderaram do Estado para 'se servir' e não para 'servir', e que dele devem ser extirpadas" (Raiz - Movimento Cidadanista, 2016, p. 219). Percebe-se que não só os ocupantes do Estado descumprem as suas funções (uma das formas de expressão do terceiro critério), como também o fazem com o objetivo de servirem a si mesmos, numa alusão também ao desvio dos próprios recursos do Estado, uma das formas mais comuns de expressão dessa retórica anti-establishment político e que demonstra o preenchimento do segundo critério. As críticas às "oligarquias" resvalam também nos próprios partidos. O aspirante a partido se coloca também como um movimento, e isso, para ele, é fundamental para alcançar "um novo patamar de democracia". Essa nova democracia seria "formada por sujeitos autônomos, potencializados em Redes Cidadãs" (p. 219) e só seria alcançada através desse novo formato, já que "Nem só Partido e nem só Movimento dão conta dessas questões. Movimentos se perdem nas pautas pontuais e Partidos se perdem na alienação do poder. Daí a necessidade de unir ambos, em conceito e forma, criando uma síntese entre pensamento e prática" (p. 219). 
Nessa nova conformação, os participantes do movimento seriam capazes de construir "pontes para o diálogo entre os cidadãos e não atalhos para as castas dirigentes" (Raiz - Movimento Cidadanista, 2016, p. 219). Ainda nessa toada crítica aos partidos, o programa aponta que o movimento deve ser "Um partido que dialogue com os movimentos sociais, mas sem cooptá-los. Um movimento social e um partido político, ao mesmo tempo" (p. 219), e que, com isso, se construiriam, "nas ruas e também nas redes que integram os 'debaixo', os legítimos donos do poder" (p. 219).

Essa crítica aos partidos existentes parece necessária às propostas que o movimento faz, já que ele se afirma representante da maioria que não é ouvida e quer ser um espaço que torne a política "apaixonante", "em que as pessoas comuns, quaisquer cidadãos, tenham capacidade e meios para interferir nos rumos da sociedade" (Raiz Movimento Cidadanista, 2016, p. 219).

Com relação às propostas para as questões políticas em geral, o movimento compartilha diversos anseios com os demais partidos mainstream e outros movimentos sociais tradicionais, tais como

Promover a auditoria cidadã da dívida pública, prevista na Constituição de 1988 e até hoje protelada; Promover a criação de um sistema tributário mais justo e progressivo, que taxe menos a renda e o consumo dos pobres e mais sobre (sic) as grandes fortunas, heranças, propriedades especulativas, lucros exorbitantes e transações financeiras internacionais (...). Reforma Política Lutar por uma reforma política, justa, democrática e cidadã, que coloque a política nas mãos das pessoas, acabando com o poder do dinheiro nas eleições e o abuso do poder, seja de governos, empresas, mídia ou igrejas; Reencantar a política, tornando-a algo apaixonante, para que seja realizada com amor (Raiz - Movimento Cidadanista, 2016, p. 219).

Mas é num contexto de crítica às instituições partidárias disponíveis e que ocuparam o poder ao longo do tempo que essas propostas são encaradas como componentes de um conjunto com retórica anti-establishment político. O apelo a grandes reformas institucionais, como a judiciária, do sistema eleitoral ou do financiamento dos partidos políticos, é comum entre os partidos anti-establishment político, como afirmam Rama Caamaño e Casal Bértoa (2019, p. 6).

\section{Partido Tribuna Popular (PTP)}

O aspirante a partido político Tribuna Popular publicou seu programa em 11 de abril de 2017. O movimento dá um subtítulo ao seu programa que indica muito bem o que será focalizado: "a corrupção é a mãe de todos os males" (Partido Tribuna Popular, 2017, p. 133). Dessa forma, o programa está voltado especialmente ao combate da corrupção, já que: "Se não enfrentarmos a corrupção generalizada do país, tudo o que colocarmos nesse programa não passará de uma promessa de político" (p. 133). É interessante notar 
que a corrupção é um dos assuntos mais comumente abordados pelos partidos antiestablishment, que acusam o mainstream de representar o jogo sujo da política, a corrupção e o clientelismo (Hartleb, 2015, p. 44).

O movimento chega a apontar algumas prioridades, áreas que receberão os recursos provenientes da recuperação dos desvios da corrupção, tais como "contratar mais servidores públicos, como médicos, enfermeiros, professores, policiais, etc.". Além disso, declara: "[n]a medida em que o governo recuperar sua capacidade de contratação de pessoal, para melhor atender à população, além de poder pagar melhores salários e aposentadorias, elevaremos o consumo, as vendas em nossas empresas, e a arrecadação de impostos" (Partido Tribuna Popular, 2017, p. 133). Tudo isso "sem gerar inflação, que só ocorre quando o governo não tem recursos para cobrir tais despesas, porque os corruptos assaltaram seus cofres" (p. 133).

O programa é, em comparação com os demais analisados aqui, relativamente curto e não apresenta propostas amplas para vários temas da política nacional, porque, de acordo com o documento, "Assim, não trazemos um programa de governo mastigado, para ser imposto à sociedade, muitas vezes até por falta de opção" (Partido Tribuna Popular, 2017, p. 133). O que se propõe é apenas "entregar aos cidadãos as ferramentas para que eles mesmos se defendam dos corruptos, e decidam com racionalidade os rumos que o país deve seguir" (p. 133).

Essas ferramentas são o segundo tema do programa, a "democracia direta" por meio de um "governo digital". Para o movimento, a democracia direta "é o império da razão e da lógica, que conseguiu desenvolver até mesmo países sem grandes recursos naturais, pacíficos, e que nem chegaram a participar da colonização das Américas e da África" (Partido Tribuna Popular, 2017, p. 133). Ou seja, afirma que a democracia direta será capaz de levar ao desenvolvimento e que há exemplos ao redor do mundo, inclusive de países que não foram colonizadores.

Percebe-se que o tema central do texto é o combate à corrupção, que serve tanto à satisfação do terceiro critério proposto por Abedi quanto à satisfação do segundo. $O$ movimento acusa os políticos de serem generalizadamente corruptos, afirmando que os "principais seguimentos políticos sujaram-se com o financiamento empresarial" (Partido Tribuna Popular, 2017, p. 133) e que, por isso, "O Brasil precisa ser passado a limpo!" (p. 133). Portanto, a retórica anticorrupção reforça a divisão entre as pessoas comuns e a elite política, porque toda ela é considerada corrupta.

Noutro ponto, ainda, o texto do documento afirma que é necessário dar ao povo ferramentas para "derrubar Leis" com o objetivo de "acabar com cada brecha deixada na Lei para a corrupção", já que seus representantes, os "políticos corruptos", negam-se a fazê-lo "por ir contra seus interesses, e os de quem Ihes financia a campanha eleitoral'" (Partido Tribuna Popular, 2017, p. 133).

No cumprimento do segundo critério, o movimento se coloca de forma diferente, como desafiante, ao afirmar que dará maior espaço aos cidadãos. Para ele, os cidadãos 
estão sendo alijados da política e serão reconduzidos a ela por meio do que denomina "democracia direta" com "governo digital". Essa proposta, praticamente a única mais concreta do texto, é o que o movimento considera como a solução para essa distinção entre o mainstream, corrupto, e os cidadãos comuns. Retorna aqui o apelo a uma democracia mais direta, voltada para a base, como exemplo importante de utilização de retórica anti-establishment político. Assim, a "proposta é dotar o povo de poderosas ferramentas de defesa contra a corrupção, descentralizando as deliberações políticas", e, "com milhões de pessoas decidindo sobre o futuro dos políticos suspeitos de corrupção, não haverá mais espaço para as vexaminosas negociatas que presenciamos" (Partido Tribuna Popular, 2017, p. 133).

Existe uma oposição entre o povo e os políticos, e ela é feita de forma própria, através da valorização da capacidade de decisão do povo em detrimento da capacidade de decisão dos políticos. O que o movimento aponta é que "os políticos são tão leigos quanto o povo, necessitando do auxílio de seus assessores, e que os corruptos enchem os bolsos de propina, justamente para votar errado lá em Brasília" (Partido Tribuna Popular, 2017, p. 133). O povo, por oposição, não incorreria nos mesmos erros, uma vez que "não tem como subornar a maioria da população, que sofre e aprende, quando erra, corrigindo-se em seguida" (p. 133).

O ataque ao sistema democrático convencional se dá de forma veemente, e a proposta de uma democracia mais plebiscitária, comum em plataformas de partidos antiestablishment político pelo mundo, se apresenta de forma contundente. Numa passagem, o programa indica que "Os abaixo-assinados do povo precisam ser reconhecidos, ganhando poder para convocar plebiscitos e referendos", embora ressalve que "o plebiscito destituinte de político" pode "exigir motivação, e valer apenas para fatos ocorridos a partir de sua instituição" (Partido Tribuna Popular, 2017, p. 133). Propõe ainda a instauração do "governo digital", que será uma "plataforma de debates na internet" na qual todos os cidadãos poderão se cadastrar, considerando que "as propostas mais apoiadas" poderão "até se transformar em plebiscitos ou referendos" (p. 133). Embora essa seja uma clara proposta em termos de grandes questões políticas, o programa acredita que a "democracia direta vem não para acabar com o atual sistema representativo, mas sim para fortalecêlo, aperfeiçoando-o e racionalizando-o. Já que o atual modelo está falido, justamente por premiar os erros, em vez dos acertos" (p. 133).

\section{Considerações finais}

O Brasil não parece ter escapado da crise dos partidos e do avanço de discursos anti-establishment político. Através dos critérios avaliados, percebe-se que há no país candidatos a partidos políticos que possuem uma retórica anti-establishment político. Embora este artigo possa corroborar a tese de que há um crescimento global de oferta de 
PÂMELA DE REZENDE CÔRTES; ANDRÉ MATOS DE ALMEIDA OLIVEIRA

discursos que desafiam o status quo, é importante levantar algumas questões metodológicas que podem ser resolvidas em pesquisas futuras.

Uma primeira questão é o fato de que não conseguimos encontrar pesquisas sobre os movimentos postulantes a partido no Brasil, que poderiam nos auxiliar na comparação entre a taxa média de sucesso no registro de partidos dos movimentos com retórica antiestablishment e aquela dos movimentos mais politicamente mainstream, e na compreensão da mudança do perfil desses movimentos desde as Jornadas de Junho de 2013. Futuras pesquisas poderão ser úteis para esclarecer esses pontos, inclusive para investigar se há uma relação causal entre as Jornadas e o surgimento desses movimentos, ou se outras situações políticas do Brasil poderiam ter levado ao surgimento de outros movimentos anti-establishment político, como o impeachment da ex-presidente Dilma em 2016 ou a Greve dos Caminhoneiros de 2018.

Em termos de aplicação da metodologia proposta por Abedi (2004), parece-nos que ela é adequada ao contexto brasileiro e pode ser usada também na análise da retórica e no reconhecimento dos movimentos postulantes a partidos, como demonstrado. Porém, não nos parece que a metodologia, sozinha, é capaz de captar todas as nuances desses movimentos e todas as possibilidades de expressão dessa retórica anti-establishment político. Para demonstrá-lo, gostaríamos de avaliar os programas de dois aspirantes a partidos políticos, o PNC, Partido Nacional Corinthiano, e o Piratas, Partido Pirata do Brasil.

O PNC está em fase final de processo de registro, sob a relatoria do ministro Jorge Mussi, do TSE (TSE, 2019). Trata-se de um caso curioso, já que, em sua legenda, o movimento busca desafiar os grupos de interesse tradicionais ou as ideologias usualmente atuantes na esfera política ao se colocar como um partido vinculado a um time brasileiro de futebol. Sua retórica, porém, é bastante moderada, e não há no programa nenhuma indicação de ataques ao establishment político, nem mesmo nenhuma referência ao próprio time do qual deriva o nome. O clube Corinthians se pronunciou em 2016, em uma nota oficial, repudiando o registro do partido e o uso do nome da agremiação para angariar votos, dizendo que não corroborava com a proposta (Folha de S. Paulo, 2016).

O movimento já fez alguns pronunciamentos políticos, como o repúdio a João Doria, ex-prefeito e atual governador de São Paulo, que tinha dito em campanha que não deixaria a prefeitura para concorrer a outros cargos (Quintella, 2018). Embora sua retórica seja moderada, é difícil não o considerar desafiante do mainstream político-partidário. Ele pretende se colocar no ambiente político não em função dos grupos de interesse usualmente reconhecidos, como trabalhadores ou ambientalistas, mas tendo como identificação uma torcida de time de futebol. A classificação proposta por Abedi coloca o movimento fora da lista, mas uma análise mais qualitativa ao menos poderia considerá-lo como atípico dentro da história político-partidária brasileira.

O Piratas, por sua vez, ainda não está em fase final de registro; o site do TSE o aponta como "ativo", mas ainda não fornece as informações dos apoiamentos nos estados brasileiros, outro requisito para a inscrição. O partido está ligado a uma família de partidos 
piratas, que se espalharam pelo mundo após o sucesso do partido pirata da Suécia, fundado em 2006, que acabou por iniciar esse movimento (Erlingsson e Persson, 2011). É marcado, assim como os outros desse grupo, pela defesa de pautas como a privacidade, o acesso à informação e a livre transmissão do conhecimento, e dá atenção às decorrências desses temas na internet. Todas essas características podem ser depreendidas da leitura do programa (Partido Pirata do Brasil, 2013). No entanto, outra característica do partido, que não pode ser depreendida diretamente da leitura do programa, mas que marca sua aparição na mídia, é a luta contra corporações e governos, as quais, segundo ele, ameaçam as liberdades individuais ao monitorar, controlar e coagir as pessoas. $O$ partido defende a reforma de leis de direitos autorais, patentes etc., para transferir esse poder das grandes corporações para o cidadão (Fredriksson, 2015, pp. 912-915). Portanto, é difícil dizer que essa luta contra o poder econômico e as formas tradicionais de tutelar a propriedade não tenha verve anti-establishment. Por não estar enunciada explicitamente no programa do partido, não passou pelo crivo de nossa metodologia. Isso levanta a possibilidade de se fazer essa análise levando-se em consideração também outros momentos de expressão desses movimentos ou de seus líderes, com o objetivo de aprofundar o estudo e ampliar o acesso à retórica.

Outra reflexão metodológica que deve ser levantada é o fato de que os critérios foram estabelecidos em 2004. Embora ainda estejam em aplicação, como demonstrado na "Introdução", muitos fatos políticos ocorreram desde então. O que se percebe é que os movimentos insurgentes em geral têm crescido em importância e, mais do que apenas no discurso, foram capazes de ocupar os espaços institucionais e tornar-se parte do establishment, embora a retórica possa não ter acompanhado essa mudança em termos de institucionalização. Essa é uma leitura possível, por exemplo, da eleição de líderes mundiais que se colocam como outsiders, como o presidente norte-americano Donald Trump e o presidente brasileiro Jair Bolsonaro. Dessa forma, pode ser interessante compreender como esses insurgentes, que possivelmente possuem uma retórica antiestablishment político, conseguiram alçar os cargos e adaptar seus discursos para manterem o apoio e o tom populista enquanto ocupam espaços convencionais.

O caso do presidente Jair Bolsonaro nos permite levantar outra reflexão, derivada da anteriormente apresentada, que é a grande quantidade de movimentos aspirantes a partidos que não conseguem se efetivar no país. Embora tenhamos uma quantidade impressionante de partidos cadastrados (35 em 2019, como apontamos), ainda há mais do que o dobro buscando cadastramento no TSE (77). Uma hipótese pode ser a de que o nosso sistema de registro de partido seja, contraintuitivamente, mais restritivo ou a de que a extensão territorial do país dificulte o apoiamento em vários estados da federação. Essas são hipóteses que poderiam ajudar a explicar por que esses aspirantes a partidos com retórica anti-establishment político analisados não conseguiram sua efetivação.

Outra hipótese, porém, seria a capacidade de esses movimentos se inserirem nos partidos já cadastrados. Não fizemos essa análise, mas é possível que alguns dos partidos 
brasileiros se utilizem de uma retórica anti-establishment político ou até mesmo tenham atuação nesse sentido. Esse seria um trabalho a ser realizado em futuras investigações. É possível tanto sua inserção em partidos já existentes como talvez sua cooptação pelos partidos com vistas a usar a retórica anti-establishment político para fins eleitorais, caso se confirme a existência de partidos de aluguel.

Também se levanta a importância de considerar os contextos na hora de classificar os aspirantes a partidos ou os partidos propriamente como movimentos com retórica antiestablishment político. É possível dizer que diversas pautas que poderiam ser mais incomuns ou absurdas em algumas democracias tornam-se senso comum ou até mesmo propostas bastante razoáveis quando transpostas a outras. Considerando, por exemplo, a diferença entre o sistema democrático brasileiro e o alemão, talvez uma crítica que, no contexto alemão, seria considerada radical e anti-establishment, aqui seja encarada como proposta razoável de reforma, compartilhada por todos os movimentos e partidos comprometidos. Algumas reformas que, em democracias mais antigas, seriam consideradas desnecessárias, em democracias recentes ou que passaram por momentos ditatoriais em sua história, podem ser necessárias para fortalecer a democracia ou melhorar o sistema representativo. O mesmo vale para outros temas como reformas envolvendo tributos, justiça eleitoral e financiamento de partidos. E essa necessária contextualização pode ajudar a explicar por que os aspirantes a partidos políticos que foram enquadrados neste artigo demonstram uma tendência mais progressista, diferente dos exemplos encontrados na literatura, que costumam ocupar a direita ou a extrema direita e ter pautas mais reacionárias.

\section{Referências bibliográficas}

Abedi, A. Anti-political establishment parties: a comparative analysis. Série Routledge Studies in Extremism and Democracy. Londres: Routledge, 2004.

ABEDI, A.; LUNDBERG, T. C. "Doomed to failure? Ukip and the organisational challenges facing rightwing populist anti-political establishment parties". Parliamentary Affairs, vol. 62, no 1, p. 72-87, 2009.

Alcántara, M.; Freidenberg, F. "Partidos políticos na América Latina". Opinião Pública, Campinas, vol. 8, n० 2, p. 137-157, 2002.

ASLANIDIS, P. "Is populism an ideology? A refutation and a new perspective". Political Studies, vol. 64, no 1, 2016, p. 88-104, 2016.

BALCERE, I. "Populism in the manifestos of Latvian political parties: increasingly used but ineffective?". Journal of Baltic Studies, vol. 45, no 4, p. 477-497, 2014.

BARR, R. R. "Populists, outsiders and anti-establishment politics". Party Politics, vol. 15, no 1, p. 2948, 2009.

BRASIL. Lei no 9.096, de 19 de setembro de 1995. Dispõe sobre partidos políticos, regulamenta os arts. 17 e 14, § 30 , inciso V, da Constituição Federal. Disponível em:

<http://www.planalto.gov.br/ccivil_03/leis/L9096.htm>. Acesso em: 27 nov. 2017. 
Resolução no 23.571, de 29 de maio de 2018. Disciplina a criação, organização, fusão, incorporação e extinção de partidos políticos. Disponível em: <https://www.tse.jus.br/legislacao/codigo-eleitoral/normas-editadas-pelo-tse/resolucao-no-23-571de-29-de-maio-de-2018-2013-brasilia-df>. Acesso em: 10 mar. 2021.

DALton, R.; MCAllister, I.; WATtenberg, M. "Democracia e identificação partidária nas sociedades industriais avançadas". Análise Social, vol. 38, no 167, p. 295-320, 2003.

Erlingsson, G. O.; Persson, M. "The Swedish Pirate Party and the 2009 European Parliament election: protest or issue voting?". Politics, vol. 31, no 3, p. 121-128, 2011.

FLINDERS, M. "The general rejection? Political disengagement, disaffected democrats and 'doing politics' differently". Parliamentary Affairs, vol. 68, no 1, p. 241-254, 2015.

FOLHA DE S. PAULO. "Corinthians repudia aprovação do Partido Nacional Corinthiano pelo TRE", 19 maio 2016. Disponível em: <https://www1.folha.uol.com.br/esporte/2016/05/1772961-corinthiansrepudia-aprovacao-do-partido-nacional-corinthiano-pelo-tre.shtml>. Acesso em: 8 mar. 2019.

FrAGA, E. "71\% dos brasileiros não têm partido de preferência". Folha de S. Paulo, Caderno Poder, 9 fev. 2015. Disponível em: <http://www1.folha.uol.com.br/poder/2015/02/1587139-71-dosbrasileiros-nao-tem-partido-de-preferencia.shtml>. Acesso em: 16 nov. 2017.

FREDRIKSSON, M. "Piracy \& social change: The Pirate Party and the politics of communication". International Journal of Communication, vol. 9, p. 16, 2015. Disponível em: <https://ijoc.org/index.php/ijoc/article/view/3742>. Acesso em: 10 mar. 2021.

Freitas, S. "Resistência Guarani-Kaiowá no Mato Grosso do Sul marca 2012". Portal EBC, 21 dez. 2012. Disponível em: <http://www.ebc.com.br/noticias/retrospectiva-2012/2012/12/resistenciaindigena-no-mato-grosso-do-sul-marca-2012>. Acesso em: 5 abr. 2019.

GoHn, M. G. "A sociedade brasileira em movimento: vozes das ruas e seus ecos políticos e sociais". Caderno $C R H$, vol. 27, no 71, 2014.

HANLEY, S.; SIKK, A. "Economy, corruption or floating voters? Explaining the breakthroughs of antiestablishment reform parties in Eastern Europe". Party Politics, vol. 22, no 4, p. 522-533, 2016.

HARTLEB, F. "Here to stay: anti-establishment parties in Europe". European View, vol. 14, no 1, p. 39-49, 2015.

HoBolt, S. B. "The Brexit vote: a divided nation, a divided continent". Journal of European Public Policy, vol. 23, no 9, p. 1.259-1.277, 2016.

INNERARITY, D. A política em tempos de indignação: a frustração popular e os riscos para a democracia. Rio de Janeiro: LeYa, 2017.

Kemmers, R.; VAn DeR WAAL, J.; Aupers, S. "Becoming politically discontented: anti-establishment careers of Dutch nonvoters and PVV voters". Current Sociology, vol. 64, no 5, p. 757-774, 2016.

KInzo, M. "Partidos, eleições e democracia no Brasil pós-1985". Revista Brasileira de Ciências Sociais, vol. 19, no 54, p. 23-51, 2004.

KROUWEL, A.; VAN ELFRINKHOF, A. "Combining strengths of methods of party positioning to counter their weaknesses: the development of a new methodology to calibrate parties on issues and ideological dimensions". Quality \& Quantity, vol. 48, no 3, p. 1.455-1.472, 2014.

LACLAU, E. La razón populista. 2a ed. México: FCE, 2006. 
LATINOBARÓMETRO. Informe Latinobarómetro 2018. Santiago de Chile. Disponível em: <www.latinobarometro.org>. Acesso em: 4 fev. 2019.

MAIR, P. Ruling the void: the hollowing of Western democracy. London/New York: Verso Books, 2013.

MARCH, L.; ROMMERSKIRCHEN, C. "Out of left field? Explaining the variable electoral success of European radical left parties". Party politics, vol. 21, no 1, p. 40-53, 2015.

MATTES, R., et al. Parties, elections, voters and democracy. In: GUNTHER, R., et al. (eds.). Voting in old and new democracies. New York: Routledge, 2015.

Moreira, O. L.; SAntiago, I. Vem Pra Rua: os protestos de junho. SousA, C. M. (org.). Jornadas de Junho: repercussões e leituras. Campina Grande: EDUEPB, p. 13-21, 2013.

MudDE, C. "The populist zeitgeist". Government and Opposition, vol. 39, n 4, p. 541-563, 2004.

Nicolau, J. "Os quatro fundamentos da competição política no Brasil (1994-2014)". Journal of Democracy, vol. 6, no 1, p. 83-106, 2017.

OdiLLA, F. "Em dois anos, partidos em formação duplicam no Brasil: 68 legendas buscam assinaturas". BBC Brasil, 24 set. 2017. Disponível em: <http://www.bbc.com/portuguese/brasil41266392>. Acesso em: 28 nov. 2017.

Partido Nacional Indígena. "Programa do Partido Nacional Indígena". Diário Oficial da União, seção 3, no 127, p. 191-193, 4 jul. 2013.

Partido Pirata do Brasil. "Programa do Partido Pirata do Brasil". Diário Oficial da União, seção 3, no 169 , p. 289,2 set. 2013.

Partido Tribuna Popular. "Programa de governo do Tribuna Popular: a corrupção é a mãe de todos os males". Diário Oficial da União, seção 3, no 70, p. 133, 11 abr. 2017.

PoLK, J., et al. "Explaining the salience of anti-elitism and reducing political corruption for political parties in Europe with the 2014 Chapel Hill expert survey data". Research \& Politics, vol. 4, no 1, 2017.

Power, T. J.; JAMISON, G. D. "Desconfiança política na América Latina". Opinião Pública, Campinas, vol. 11 , no 1 , p. 64-93, mar. 2005.

QUiNTELLA, S. "Partido Nacional Corinthiano pede condenação de João Doria". Veja SP, 22 mar. 2018. Disponível em: <https://vejasp.abril.com.br/cidades/partido-nacional-corinthiano-pede-condenacaode-joao-doria/>. Acesso em: 8 mar. 2019.

Raiz - Movimento Cidadanista. "Programa Partidário da Raiz - Movimento Cidadanista". Diário Oficial da União, seção 3, no 86, p. 218-219, 6 maio 2016.

RAma CAAmaño, J.; CASAl BÉRtoA, F. "Are anti-political-establishment parties a peril for European democracy? A longitudinal study from 1950 till 2017". Representation, p. 1-24, 2019.

RYDGREN, J. "Is extreme right-wing populism contagious? Explaining the emergence of a new party family". European Journal of Political Research, vol. 44, no 3, p. 413-437, 2005.

Schedler, A. "Anti-political-establishment parties". Party Politics, vol. 2, no 3, p. 291-312, 1996.

Schumacher, G.; VAn Kersbergen, K. "Do mainstream parties adapt to the welfare chauvinism of populist parties?". Party Politics, vol. 22, no 3, p. 300-312, 2016. 
Singer, A. "Brasil, junho de 2013, classes e ideologias cruzadas". Novos Estudos - Cebrap, São Paulo, no 97, p. 23-40, nov. 2013.

SмITH, J. M. "Does crime pay? Issue ownership, political opportunity, and the populist right in Western Europe". Comparative Political Studies, vol. 43, n 11, p. 1.471-1.498, 2010.

TODOROv, T. Os inimigos íntimos da democracia. São Paulo: Companhia das Letras, 2012.

TSE. Tribunal Superior Eleitoral. "Brasil tem 75 partidos políticos em processo de formação", 25 jan. 2019. Disponível em: <http://www.tse.jus.br/imprensa/noticias-tse/2019/Janeiro/brasil-tem-75partidos-politicos-em-processo-de-formacao>. Acesso em: 8 mar. 2019.

VAN KESSEL, S. "Explaining the electoral performance of populist parties: the Netherlands as a case study". Perspectives on European Politics and Society, vol. 12, no 1, p. 68-88, 2011.

VAN SPANJE, J. "Keeping the rascals in: anti-political-establishment parties and their cost of governing in established democracies". European Journal of Political Research, vol. 50, no 5, p. 609-635, 2011.

ZUCCO JR., C. Estabilidad sin raíces: institucionalización de sistemas de partidos en Brasil. In: TORCAL, M. (coord.). Sistemas de partidos en América Latina. Barcelona: Anthropos Editorial; Santa Fe, Argentina: Ediciones Universidad Nacional del Litoral, Siglo XXI, p. 78-107, 2015.

ZULIANELLO, M. "Anti-system parties revisited: concept formation and guidelines for empirical research". Government and Opposition, vol. 53, no 4, p. 653-681, 2018

\begin{abstract}
Political parties in formation in post-2013 Brazil and the anti-political establishment rhetoric

The aim of this paper is to know whether, between 2013 and 2017, there were movements with antiestablishment political rhetoric who applied to become political parties in Brazil. Our evaluation will be empirical-descriptive, and will analyze the party programs used in registrations after the 2013 Protests in Brazil. To ground the concept of an anti-political establishment rhetoric, we will use the three criteria proposed by Abedi (2004). Based on the analysis of these data, and based on these criteria, we conclude that there were, in Brazil, parties trying to register that had an anti-establishment political rhetoric. Having this information is important to understand our political situation, especially in view of the relevance of the topic for contemporary democracies. As the article analyzes objects that do not usually receive much empirical attention, political parties in formation can contribute with reflections on the appropriate methodology for analyzing them, as well as for analyzing the antipolitical establishment rhetoric in politics.
\end{abstract}

Keywords: formation of political parties; populism; anti-establishment movements; political parties programs; 2013 protests in Brazil

\title{
Resumen
}

Partidos políticos en formación en Brasil después de 2013 y la retórica anti-establishment político

El propósito de este artículo es averiguar si, entre 2013 y 2017, hubo movimientos con retórica política antisistema que se aplicaron para convertirse en partidos políticos en Brasil. La evaluación será empírica-descriptiva, analizando los programas de los partidos que intentaron registrarse después de los días de junio de 2013. Para conceptualizar la retórica de un movimiento como un antiestablecimiento político, se utilizarán los tres criterios propuestos por Abedi (2004). Con base en el análisis de estos datos, y en base a estos criterios, se concluye que hubo, en Brasil, durante el período estudiado, partidos en formación que tenían retórica política antisistema. Obtener esta información es importante para comprender nuestra situación política, especialmente en vista de la importancia del tema para las democracias contemporáneas. A medida que el artículo analiza objetos que generalmente no reciben mucha atención empírica, los partidos políticos en formación pueden 
contribuir con reflexiones iniciales sobre la metodología apropiada para analizarlos, así como para analizar la retórica política anti-establecimiento.

Palabras clave: formación de partidos políticos; populismo; movimientos anti-establishment político; programa de partidos políticos; protestas de 2013 en Brasil

\section{Résumé}

Partis politiques en formation au Brésil après-2013 et la rhétorique anti-establishment politique

Le but de cet article est de savoir s'il y a eu, entre 2013 et 2017, des mouvements à rhétorique politique anti-établissement qui ont demandé à devenir des partis politiques au Brésil. L'évaluation sera empiriquement descriptive, en analysant les programmes des partis qui ont tenté de s'inscrire après les Journées de juin 2013. Pour conceptualiser la rhétorique d'un mouvement comme antiétablissement politique, les trois critères proposés par Abedi (2004) seront utilisés. Sur la base de l'analyse de ces données, et sur la base de ces critères, il est conclu qu'il y avait, au Brésil, au cours de la période étudiée, la formation de partis qui avaient une rhétorique politique anti-établissement. L'obtention de ces informations est importante pour comprendre notre situation politique, compte tenu notamment de l'importance du sujet pour les démocraties contemporaines. Comme l'article analyse des objets qui ne reçoivent généralement pas beaucoup d'attention empirique, les partis politiques en formation peuvent apporter des réflexions initiales sur la méthodologie appropriée pour les analyser, ainsi que pour analyser la rhétorique politique anti-établissement.

Mots-clés: formation de partis politiques; le populisme; mouvements anti-établissement politique; programme des partis politiques; manifestations de 2013 au Brésil

Artigo submetido à publicação em 14 de junho de 2019. Artigo ressubmetido à publicação em 20 de abril de 2020. Versão final aprovada em 15 de janeiro de 2021.

Opinião Pública adota a licença Creative Commons CC-BY. 